\title{
Zofia WILK-WOŚ*
}

\section{O PLEBANACH MIEJSKIM I WIEJSKIM W UNIEJOWIE W XV WIEKU}

\begin{abstract}
Zarys treści: Parafia uniejowska należała do nielicznych w Polsce parafii o wieloosobowej obsadzie plebańskiej. W XV wieku w Uniejowie opiekę duszpasterską sprawowało dwóch proboszczów: pleban wiejski - wiceprepozyt oraz pleban miejski - wicearchidiakon. Celem artykułu jest przybliżenie zagadnienia wieloosobowych parafii oraz odtworzenie i scharakteryzowanie piętnastowiecznej grupy proboszczów parafii uniejowskiej. W pracy przedstawiono również kwestie regulacji majątkowych i wzajemnych relacji między plebanami uniejowskimi.
\end{abstract}

Słowa kluczowe: Uniejów, księża parafialni, XV wiek

Zazwyczaj na czele parafii stał jeden pleban, jednak czasami spotykamy się z wieloosobową obsadą plebańską. Taką sytuację mieliśmy w parafii uniejowskiej, którą administrowało dwóch proboszczów - pleban miejski i pleban wiejski. Celem artykułu jest przybliżenie zagadnienia wieloosobowych parafii oraz odtworzenie i scharakteryzowanie piętnastowiecznej grupy proboszczów parafii uniejowskiej. W pracy zostaną również przedstawione kwestie regulacji majątkowych i wzajemnych relacji między plebanami uniejowskimi.

Zjawisko wieloosobowych parafii w średniowiecznej Polsce nie zostało jeszcze do końca wyjaśnione. Istotnym problemem pozostaje kwestia przyczyn powstania parafii z wieloosobową obsadą. Na obszarze diecezji gnieźnieńskiej zjawisko to było jednak rzadkością. Oprócz Uniejowa dwóch plebanów miała parafia w Łeknie ${ }^{1}$, a trzech - parafia w Chełmie ${ }^{2}$. Kilka kościołów z liczniejszą obsadą plebańską funkcjonowało w diecezji włocławskiej (Kościelec, Kościelna Wieś, Piotrków Kujawski, Płonikowo i Służewo)³. Najwięcej przykładów

*Zofia Wilk-Woś, dr hab., prof. SAN, Społeczna Akademia Nauk w Łodzi, ul. Sienkiewicza 9, 90-113 Łódź.

${ }^{1}$ Kodeks dyplomatyczny Wielkopolski (dalej: KDW), t. 3, wyd. I. Zakrzewski, Poznań 1879, nr 1631; J. Łaski, Liber beneficiorum archidiecezji gnieźnieńskiej (dalej: LB), wyd. J. Łukowski, t. 1, Gniezno 1880, s. 106.

${ }^{2}$ LB, t. 2, Gniezno 1881, s. 200-204; A. Kowalska-Pietrzak, Duchowieństwo parafialne w późnośredniowiecznej Polsce centralnej. Archidiakonat tęczycki i uniejowski, Łódź 2014, s. 203-204.

${ }^{3}$ M. Osmałek, Parafie z wieloosobowa obsada plebańska $w$ diecezji krakowskiej $w$ średniowieczu, „Summarium. Sprawozdania TN KUL”, 26-27 (46-47), 1997/1998, s. 37. 
zaobserwowano w średniowieczu na obszarze diecezji krakowskiej, gdzie naliczono aż 27 parafii z większą liczbą proboszczów ${ }^{4}$. Władysław Abraham próbował tłumaczyć to zjawisko „stosunkami patronatowymi”. Uważał, że czasem mogła przyczynić się do niego niezgoda między patronami w kwestii wyznaczenia jednego kandydata na stanowisko proboszcza ${ }^{5}$. Na taką przyczynę wskazywał już Jan Długosz w przypadku kościoła Wszystkich Świętych w Krakowie (patronis vero discordantibus, creatae sunt due plebaniae) ${ }^{6}$. Bardziej prawdopodobny był jednak dla Abrahama inny powód. Badacz przypuszczał, że koszty wymurowania i wyposażenia kościoła parafialnego były zbyt znaczne dla jednego właściciela, stąd wznosił on świątynię wspólnym kosztem z sąsiadami, którzy godzili się na to pod warunkiem, że każdy z nich będzie miał dla swoich dóbr osobnego plebana ${ }^{7}$. Karol Maleczyński szukał rozwiązania problemu w połączeniu dwóch kościołów lub we wpływie kolonizacji niemieckiej i ustanowieniu osobnych kapłanów dla ludności polskiej i niemieckiej ${ }^{8}$. Zdaniem Józefa Szymańskiego kilku plebanów w jednej parafii mogło być reliktem funkcjonowania w XI-XII wieku małych grup kanonickich przy kościołach w siedzibach rodowych lub centrach majątkowych możnowładztwa9.

W Annales pod datą 1365 r. Jan Długosz zanotował, że archiepiscopus Iaroslaus de Bogoria castro pulcerrimo Vnyeow ad flumen Wartha coctili muro perfecto ecclesiam collegiatam in opido Vnyeyow simili muro fundat, erigit et consumat duosque prelatos, videlicet prepositum et archidiaconum, item quinque canonicatus et prebendas, septem quoque vicarios in ea creans, dotem sufficientem cuilibet adiungit, ecclesiam quoque ipsam Beatissime Virgini Marie dedicat ${ }^{10}$. Badacze datują jednak powstanie kolegiaty uniejowskiej na około 1170 r., kiedy to w Uniejowie odbyć się miała konsekracja biskupa płockiego Lupusa. Kapituła miała powstać i początkowo funkcjonować przy kościele lub kaplicy grodowej św. Wojciecha, w słowach dziejopisarza zaś widzą informacje o wtórnej fundacji i erekcji kapituły, której życie zostało zdezorganizowane

${ }^{4}$ Tamże, s. 37 i n.; por. J. Szymański, Wokół genezy organizacji parafialnej w Polsce, „Przegląd Historyczny”, 55, z. 3, 1964, s. 503; E. Wiśniowski, Parafie w średniowiecznej Polsce. Struktura i funkcje spoleczne, Lublin 2004, s. 58.

${ }^{5}$ W. Abraham (rec.), Schmid H. F., Die rechtlichen Grundlagen der Pfarrorganisation auf westslavischem Boden und ihre Entwicklung während des Mittelalters, „Kwartalnik Historyczny”, 44, 1930, s. 591.

${ }^{6}$ J. Długosz, Liber beneficiorum dioecesis Cracoviensis, wyd. A. Przeździecki, t. 2, Kraków 1864, s. 6.

${ }^{7}$ W. Abraham (rec.), Schmid H. F. ..., s. 591.

${ }^{8}$ K. Maleczyński (rec.), Michael Edmund: Die schlesische Kirche und ihr Patronat. I. Die Schlesische Kirche und ihr Patronat im Mittelalter unter polnischem Recht. Beiträge zur ältesten schlesischen Kirchengeschichte. Görlitz, Reiber (1926), str. 288, mapa, „Kwartalnik Historyczny”, 41, 1927, s. 624.

9 J. Szymański, Wokót genezy..., s. 503-507.

${ }^{10}$ Joannis Dlugossi Annales seu Cronicae incliti Regni Poloniae, lib. 9, Varsaviae 1978, s. 329. 
w wyniku niszczycielskiego najazdu krzyżackiego ${ }^{11}$. W pracach tych nie ma jednak odniesienia do kwestii genezy wieloosobowej obsady parafii uniejowskiej. Obecność dwóch plebanów w Uniejowie można próbować wytłumaczyć, sięgając do przedstawionej powyżej hipotezy Szymańskiego. Przyją́ można, że w XII wieku w Uniejowie, który stanowił centrum zwartego kompleksu dóbr kościelnych, ulokowana została przez arcybiskupa gnieźnieńskiego mała grupa kanonicka. Kanonicy ci zajmowali się duszpasterstwem, być może odgrywali również jakąś rolę w zarządzaniu dobrami biskupimi. W XIV wieku po najeździe krzyżackim, który zniszczył miasto i kościół, arcybiskup Jarosław Bogoria ze Skotnik postanowił zreformować istniejącą grupę kanonicką, przekształcając ją ostatecznie w kapitułę kolegiacką. Arcybiskup wzniósł także nową murowaną świątynię kolegiacką, której konsekracja według Jana Długosza odbyła się w 1365 r. ${ }^{12}$ Sladem istnienia wcześniejszej grupy kanonickiej byłby fakt złączenia ze zreformowaną kolegiatą obowiązku cura animarum. W ten sposób w późnym średniowieczu kościół Najświętszej Marii Panny i św. Floriana w Uniejowie pełnił dwojakie funkcje - był jednocześnie kościołem kolegiackim i parafialnym. Funkcji plebańskich nie sprawowali jednak kanonicy, a zostały one przekazane wikariuszom prepozyta i archidiakona.

Uniejów nie był fundacją odosobnioną, prawdopodobnie arcybiskupi gnieźnieńscy osadzili na podobnych zasadach małe grupy kanonickie w Kurzelowie i Rudzie. Podobnie jak w Uniejowie kolegiaty NMP w tych miejscowościach były później także kościołami parafialnymi. W Kurzelowie obowiązki związane z cura animarum spoczywały na wikariuszu dziekana, nazywanym wicedziekanem, a w Rudzie - na specjalnym wikariuszu, nazywanym plebanem. Zapewne do uniejowskiej zbliżona była fundacja biskupów krakowskich w Kielcach. Tam obowiązki duszpasterskie po reorganizacji grupy kanonickiej ostatecznie spoczęły na kustoszu i jego wikariuszu ${ }^{13}$.

Piętnastowieczną parafią uniejowską administrowało dwóch proboszczów. Pierwszy, zwany wiceprepozytem, wybierany przez prepozyta, pełnił funkcję plebana wiejskiego (plenabus villanorum), drugi - wicearchidiakon, wskazywany przez archidiakona, był plebanem miejskim (plebanus oppidanorum). Parafia uniejowska swoim zasięgiem obejmowała miasto Uniejów oraz 27 okolicznych wsi. Nad miastem i jego przedmieściami jurysdykcję sprawował pleban miejski, wobec mieszkańców wsi natomiast obowiązki duszpasterskie wypełniał pleban wiejski. Liber beneficiorum informuje nas, że oprócz obowiązków plebańskich (administracja parafią, udzielanie sakramentów i sakramentaliów, odprawianie mszy świętych i głoszenie kazań, strzeżenie moralności i prawowierności parafian), wiceprepozyt musiał wypełniać także powinności wikariusza wieczystego

${ }^{11}$ W. Kujawski, Rola instytucji kościelnych w życiu miasta, [w:] Uniejów. Dzieje miasta, red. J. Szymczak, Łódź-Uniejów 1995, s. 374-376; A. Jabłońska, Kapituła uniejowska do początków XVI wieku, Kielce 2005, s. 22-24.

${ }^{12}$ M. Bilska-Ciećwierz, Powstanie i organizacja kapitut kolegiackich metropolii gnieźnieńskiej w średniowieczu, Kraków 2007, s. 22.

${ }^{13}$ Tamże, s. 20-29. 
w kolegiacie: singulis diebus in choro eiusdem ecclesiae collegiatae cum aliis vicariis ipsius ecclesiea horas canonicas, missas, et alia sacra et divina officia cantare, peragere, explere ${ }^{14}$. Prawdopodobnie zbliżone powinności dotyczyły wicearchidiakona. Niestety Liber beneficiorum ilustruje nam stan późniejszy, po przejęciu obowiązków plebana miejskiego przez kolegium mansjonarzy.

Wieloosobowej obsady plebańskiej nie przewidywało prawo kanoniczne, więc $\mathrm{w}$ późnym średniowieczu nasilają się dążenia ze strony władz Kościoła do likwidacji tej formy opieki duszpasterskiej nad parafią. W drugiej połowie XIV i XV w. część kościołów o wieloosobowej obsadzie proboszczowskiej zamieniona zostaje na tzw. prepozytury, kolegia składające się z prepozyta i mansjonariuszy, czyli wikariuszy wieczystych zobowiązanych zarówno do cura animarum, jak i do obowiązku chórowego divinum officium. Zamiana podwójnych probostw na prepozytury stała się więc typowym sposobem na likwidację zjawiska, które Kościół postrzegał jako anomalię ${ }^{15}$. I tak z 27 kościołów w diecezji krakowskiej w wieku XIV-XV utraciło podwójne lub potrójne obsady aż 22, a pozostałych 5 funkcjonowało jeszcze w XVI w., ale i one do końca tego stulecia zostały przekształcone w normalnie działające parafie, przy czym czasem nie przekształcano godności plebańskich w mansjonarię, ale likwidowano stanowisko drugiego proboszcza po jego śmierci, nie obsadzając już go kolejną osobą, a czasem to decyzja biskupa znosiła drugiego plebana ${ }^{16}$.

Czy i w przypadku Uniejowa pewne zmiany, które dokonują się w organizacji zarządu parafią w końcu XV - zamiana wicearchidiakonatu na kolegium mansjonarzy - także należy wiązać z próbą likwidacji tej nietypowej sytuacji? Kolegium mansjonarzy powołał 28 IV 1491 r. arcybiskup gnieźnieński Zbigniew Oleśnicki. Miało się ono składać z siedmiu prezbiterów, nad którymi zwierzchnictwo sprawował archidiakon. On też prezentował duchownych na mansjonarzy, tak jak wcześniej swego wikariusza. Do uposażenia tego kolegium arcybiskup włączył również uposażenie parafii pod wezwaniem Podwyższenia Krzyża Świętego w Spycimierzu, jednocześnie powierzając tę parafię opiece duszpasterskiej mansjonarzy. Obok przejętych obowiązków plebańskich w Uniejowie i Spycimierzu mansjonarze mieli dźwięcznym głosem (voce sonorosa) wyśpiewywać officium ku NMP w kościele kolegiackim. Ponadto byli zobowiązani do aniwersarzy i hebdomad, każdy też powinien czytać mszę kapłańską. Arcybiskup zobowiązał również każdego członka kolegium do odprawiania każdego tygodnia dwóch mszy czytanych w jego intencji, a po śmierci fundatora - za spokój jego duszy i jego następców. Mansjonarze mieli ponadto odprawiać „Memento” za spokój dusz dobrodziejów parafii spycimierskiej. W dzień pogrzebu arcybiskupa mieli zaśpiewać dziewięciosekcyjne wigilie i msze święte, a w rocznicę jego śmierci każdy mansjonarz zobowiązany został do odprawienia mszy czytanej ${ }^{17}$.

${ }^{14}$ LB, t. 1, s. 344.

${ }^{15}$ J. Szymański, Wokół genezy..., s. 503-504.

${ }^{16}$ E. Wiśniowski, Parafie..., s. 60; M. Osmałek, Parafie..., s. 43-45.

${ }^{17}$ LB, t. 1, s. 346, 355-357; A. Jabłońska, Kapituła..., s. 36; W. Kujawski, Rola instytucji..., s. 388 . 
Obok uregulowań dotyczących podziału terenu parafii znany jest także podział dochodów przysługujących każdemu z proboszczów. W świetle Liber beneficiorum na uposażenie plebana miejskiego, wicearchidiakona, składała się działka w Uniejowie z domkiem koło kościoła oraz plac koło kaplicy Bożego Ciała, do którego przylegał ogród. Posiadał on również folwark oraz łan, z którego dzierżawcy płacili potem mansjonarzom czynsz roczny w wysokości 2 grzywien. Pleban miejski czerpał również dochody z kolędy i mesznego w wysokości 1 gr z domu mieszczańskiego i $1 \frac{1}{2}$ gr od komorników w Uniejowie ${ }^{18}$.

Pleban wiejski, wiceprepozyt, miał w Uniejowie działkę z domem, drugą działkę na przedmieściu koło bramy oraz ogród. Otrzymywał dziesięcinę z pól folwarcznych we wsiach Ułany i Lipnica podwójną, dziesięcinę z pól kmiecych z miejscowości Kuczki, Grocholice, Lekaszyn, Wielki Łęg, Brzozówka, Kozubów i Sarbice, z Grocholic również dziesięcinę konopną w wysokości 2 gr $\mathrm{z}$ łanu. Dostawał ponadto dziesięcinę wysokości $20 \mathrm{gr}$ z pól należących do wójta. Mieszkańcy wsi w okręgu parafialnym płacili mu także kolędę i meszne: kmiecie z miejscowości Czepów, Orzeszków, Ostrowsko, Kuczki, Szarów, Zalesie, Bronów po 1 korcu pszenicy; zagrodnicy z wsi Czepów, Orzeszków, Ostrowsko, Kuczki po 1 gr, natomiast z wsi Grocholice, Dominikowice, Balin, Krajkowice, Skotniki i Lipnica - kmiecie po $1 \mathrm{gr}$, a zagrodnicy po $1 / 2 \mathrm{gr}$. Pleban wiejski otrzymywał również kolędę i meszne w wysokości $1 \frac{1}{2}$ gr od mieszkających przy młynach oraz od rybaków, a także z Boczków, Wieścic i Kawęczyna; 1 korzec mąki pszennej od młynarza, 2 korce pszenicy i 3 korce owsa z łanu z Woli oraz 1 korzec owsa z Ubysławia ${ }^{19}$.

Pierwsza wzmianka o plebanie uniejowskim jest bardzo późna, pochodzi dopiero z początków XV w. Wcześniejsze są natomiast informacje o prałatach i kanonikach uniejowskich. Pierwszy kanonik Nikulon znany jest $\mathrm{z}$ dokumentu księżnej Eufrozyny z 1292 r., prepozyta uniejowskiego Grzegorza Węgrzyna wymienia dokument z 1294 r., a archidiakon Stanisław świadkował w dokumencie z $1301 \mathrm{r}^{20}$ Źródła nie zawsze informują nas, czy dany duchowny był plebanem miejskim, czy wiejskim, często w zapisach pojawia się jedynie określenie „pleban uniejowski”. Pierwszym znanym nam plebanem uniejowskim był Witalis zapewne z Pągowa. Wystąpił on jako świadek w dokumencie arcybiskupa gnieźnieńskiego Mikołaja Kurowskiego z 1407 r. ${ }^{21}$ Być może był on plebanem miejskim, gdyż z tego samego okresu znamy plebana wiejskiego i wiceprepozyta Stanisława (1404-1419)22. Na pewno jasną sytuację mamy w roku 1415. W księgach konsystorskich zachował się bowiem dokument Mikołaja plebana miejskiego (plebanus civitatensis), w którym wzywał on Wita, plebana z Wielenina do zadośćuczynienia za szkody wyrządzone Janowi, plebanowi z Brudzewa.

${ }^{18}$ LB, t. 1, s. 346-347.

${ }^{19}$ LB, t. 1, s. 344-345.

${ }^{20} \mathrm{KDW}$, t. 2, nr 688, 835; A. Jabłońska, Kapituła..., s. 106-107, 127, 180; M. Bilska-Ciećwierz, Powstanie..., s. 23.

${ }^{21}$ KDW, t. 5, nr 109; A. Kowalska-Pietrzak, Duchowieństwo..., Łódź 2014, s. 143.

${ }^{22}$ A. Kowalska-Pietrzak, Duchowieństwo..., s. 143. 
Jednym ze świadków był wtedy Stanisław viceprepositus et plebanus villanorum. Obaj plebani występują również $\mathrm{w}$ dokumencie z września $1415 \mathrm{r}^{23}$ Stanisław w tym samym roku został pozwany przez Jakuba z Jeziorska, prepozyta uniejowskiego, o pewne opłaty na rzecz kościoła w Uniejowie. Dwa lata później pleban uniejowski Stanisław został zobowiązany do zapłacenia Lambertowi 10 florenów węgierskich i 1 grzywny ${ }^{24}$. W 1417 roku jako pleban w Uniejowie został odnotowany Stefan, który wiódł spory z Janem, plebanem z Brudzewa oraz Piotrem, dziedzicem Woli o dziesięcinę z folwarku z Woli ${ }^{25}$. W 1440 roku plebanem wiejskim w Uniejowie był Jakub, sprawujący jednocześnie urząd oficjała uniejowskiego. Jest on zapewne tożsamy z Jakubem, kanonikiem i oficjałem uniejowskim. Jakub był również plebanem w Niemysłowie ${ }^{26}$. W świetle badań Alicji Szymczakowej należy go identyfikować z Jakubem z Gawłowic ${ }^{27}$. W 1423 roku Jakub, syn Piotra z Gawłowic, admitował się w Gnieźnie ${ }^{28}$, czyli późniejszy pleban uniejowski posiadał uprawnienia notariusza publicznego. Dzięki sporowi o obszar jurysdykcji znamy imiona obu proboszczów uniejowskich z nieco późniejszego okresu. W latach 1443-1448 plebanem wiejskim był Adam, a w latach 1442-1448 plebanem miejskim - Mikołaj ${ }^{29}$. Warto nadmienić, że Adam był kilka razy świadkiem w aktach arcybiskupich ${ }^{30}$.

W 1468 roku plebanem wiejskim był Maciej z Wojnicza, w 1470 r. zaś plebanem miejskim był Jan Ristek, który sprzedał za 12 grzywien dziesięciny Boleście ${ }^{31}$. Następnego plebana miejskiego odnajdujemy w źródłach w 1482 r. Był nim Piotr, który będzie proboszczem jeszcze w $1488 \mathrm{r}$. Zmarł on przed 3 VIII 1490 r., gdy burmistrz i rajcy uniejowscy składali przed arcybiskupem poręczenie za Stanisława z Koła, wikariusza olim Petri plebani oppidanorum in Vnyeow ${ }^{32}$. Rozpatrywany był spór o rzeczy po byłym plebanie uniejowskim. Z roku 1482 znamy również drugiego plebana uniejowskiego Jana Dundę (pleban wiejski) ${ }^{33}$. Niedługo później Jana na stanowisku plebana wiejskiego zastąpił jednak Leonard z Oleśnicy, który z tą godnością występuje w źródłach od 1483 r. Jest on chyba jednym z najbardziej interesujących piętnastowiecznych proboszczów

${ }^{23} \mathrm{KDW}$, t. 7, nr 750, 768.

${ }^{24}$ A. Kowalska-Pietrzak, Spory duchownych i świeckich w Polsce centralnej, [w:] Dynamika przemian społecznych i religijnych $w$ średniowieczu, red. T. Grabarczyk, T. Nowak, Warszawa 2011, s. 86, 87.

${ }^{25}$ A. Kowalska-Pietrzak, Spory..., s. 82, 85.

${ }^{26}$ A. Gąsiorowski, I. Skierska, Oficjalaty okręgowe w późnośredniowiecznej archidiecezji gnieźnieńskiej, „Czasopismo Prawno-Historyczne”, 47, 1995, s. 122-123.

${ }^{27}$ A. Szymczakowa (rec.), A. Jabłońska, Kapituła uniejowska do poczatku XVI wieku, Kielce 2005, s. 218, „Rocznik Łódzki”, 52, 2005, s. 298.

${ }^{28}$ A. Gąsiorowski, Notariusze publiczni w Wielkopolsce schylku wieków średnich, Poznań 1993, nr 153, s. 27.

${ }^{29}$ AAAG, ACap., A1, k. 51v; A. Kowalska-Pietrzak, Duchowieństwo..., s. 143.

${ }^{30}$ AAG, ACap., A1, k. 51, 52v, 56, 75, 83v, 89v.

${ }^{31}$ AAG, ACap., A2, k. 38v (AC, t. 2, nr 620), 62.

${ }_{32}$ AAG, ACap., A3, k. 26-26v, 46v, 169; ACons., B3, k. 192.

${ }^{33}$ AAG, ACap., A3, k. 26-26v, 35. 
uniejowskich. Był spokrewniony $\mathrm{z}$ arcybiskupem gnieźnieńskim i prymasem Zbigniewem Oleśnickim, któremu zawdzięczał karierę. Pełnił funkcję kapelana na jego dworze ${ }^{34}$. Zapewne dzięki jego protekcji objął beneficjum uniejowskie. Kilka miesięcy później, 3 VI 1484 r. Leonard otrzymał prowizję na kanonikat łęczycki wakujący po śmierci Jana Pieniążka ${ }^{35}$. Beneficjum to utrzymał aż do śmierci. Posiadał również godność kanonika łowickiego i uniejowskiego ${ }^{36}$. Leonard posiadał wyższe święcenia kapłańskie, w 1489 r. został wyświęcony na prezbitera, a jako beneficjum podano parafię wiejską w Uniejowie. W 1497 roku wystąpił także z godnością kantora opatowskiego ${ }^{37}$. Troszcząc się o los kapłanów emerytów, Leonard postanowił założyć dla nich przytułek. W tym celu kupił za 330 grzywien wójtostwo uniejowskie i oddał je arcybiskupowi Janowi Łaskiemu na utrzymanie przełożonego tego domu-przytułku ${ }^{38}$. Leonard na stanowisku plebana wiejskiego pozostał prawdopodobnie aż do śmierci. Jako plebana wymienia go bowiem Liber beneficiorum. Zmarł między 1514 a 1522 r. Pochowany został w Tumie (w kolegiacie znajdowała się poświęcona mu tablica nagrobna). $\mathrm{Z}$ osobą Leonarda i sprawowaną przez niego funkcją plebana uniejowskiego wiąże się jeszcze jedna interesująca kwestia. Gdy w roku 1488 Leonard, pleban wiejski w Uniejowie, prowadził spór z Janem Sakowskim, plebanem w Wieleninie i wikariuszem wieczystym uniejowskim, jako świadkowie zeznawali wtedy Piotr, pleban miejski w Uniejowie i Mikołaj z Turu, wiceprezpozyt uniejowski ${ }^{39}$. Zgodnie z zapisami z Liber beneficiorum Leonard jako pleban wiejski powinien jednocześnie pełnić funkcję wikariusza stałego prepozyta uniejowskiego, czyli wiceprepozyta. Dlaczego więc akta sądowe sugerują rozdzielenie funkcji plebana wiejskiego i wiceprepozyta. To rozdzielenie możemy obserwować także w nieco późniejszym okresie, jako że plebanem wiejskim nadal jest Leonard, natomiast jako wiceprepozyt występuje w źródłach Jan Sakowski. Czy w tej sytuacji można także doszukiwać się próby unormowania kwestii prawnej parafii uniejowskiej? Obowiązki wiceprepozyta zostałyby w ten sposób ograniczone do spraw związanych z kolegiatą i funkcją zastępcy prepozyta oraz wikariusza wieczystego, plebanowi wiejskiemu zaś pozostałyby tylko typowe powinności proboszczowskie. Należy pamiętać, że częsta w średniowieczu praktyka kumulacji beneficjów powodowała, że duchowni nie byli w stanie osobiście wykonywać swoich obowiązków. Ustawodawstwo kościelne dopuszczało możliwość nierezydencji przy swoim kościele, zobowiązywało jednak duchownych, w tym

${ }^{34}$ Z. Wilk-Woś, Późnośredniowieczna kancelaria arcybiskupów gnieźnieńskich (1437-1493), Łódź 2013, s. 216.

${ }^{35}$ Acta Camerae Apostolicae, t. 4: Annatae e Regno Poloniae saeculi XV (1421-1503), wyd. M.D. Kowalski, [w:] Monumenta Poloniae Vaticana, t. 10, Kraków 2002, nr 873.

${ }^{36} \mathrm{~J}$. Wieteska, Katalog prałatów i kanoników prymasowskiej kapituly towickiej od 1433 do 1470 r., Warszawa 1971, s. 33; A. Kowalska-Pietrzak, W kręgu średniowiecznego duchowieństwa tęczyckiego, Łódź-Łęczyca 2012, s. 41, 145.

${ }^{37}$ Wykazy święconych z najstarszej księgi akt działalności biskupów włocławskich, wyd. W. Kujawski, „Archiwa, Biblioteki i Muzea Kościelne”, 72, 1999, s. 40, 42.

${ }^{38}$ LB, t. 2, s. 362, przypis 1.

${ }^{39}$ AAG, ACons., B3, k. 192-193. 
plebanów, do zapewnienia na czas swojej nieobecności odpowiedniego zastępcy. Nawet w Liber beneficiorum pojawia się zapis, że wiceprepozyt może pewne obowiązki wypełniać per se vel substitutum suum. Istniała jeszcze jedna możliwość, która mogła tłumaczyć omawianą sytuację - oddanie przez plebana swojego beneficjum w dzierżawę za roczny czynsz.

Funkcję wiceprepozyta pełnili wspomniani wyżej bliżej niezidentyfikowany Mikołaj z Turu oraz Jan Sakowski (Żakowski). Jan być może pochodził z Sakowic (Żakowic), parafia Świnice (obecnie Saków). Był plebanem w Wieleninie $(1482-1489)^{40}$, oficjałem i tenutariuszem łęgonickim (1482) oraz wikariuszem wieczystym w Uniejowie. Z funkcją wiceprepozyta uniejowskiego wystąpił po raz pierwszy w kwietniu 1491 r., następnie w 1495 i 1497 r. Sakowski był również oficjałem uniejowskim w latach 1496-149941.

Następcą wspomnianego wyżej Piotra, plebana miejskiego, był natomiast Jan z Wagańca. Jan, syn Jakuba z Wagańca, pochodził z diecezji włocławskiej. Był notariuszem publicznym i dokonał admisji w 1482 r. w Uniejowie. Jako notariusz publiczny został zatrudniony w kancelarii arcybiskupa gnieźnieńskiego Zbigniewa Oleśnickiego. Stale przebywał u boku arcybiskupa, o czym świadczy liczba wystąpień w formule świadków w arcybiskupiej księdze wpisów ${ }^{42}$. W Łowiczu kolejno w sobotę 4 IV 1489 r. oraz w Wielką Sobotę 18 IV 1489 r. przyjął z prowizji arcybiskupa święcenia subdiakonatu i diakonatu, a rok później w sobotę 23 III 1490 r. został wyświęcony na kapłana ad certum titulum sue parrochialis ecclesie opidi Unyeow ${ }^{43}$. Początkowo Jan był plebanem w Malanowie, a potem w Uniejowie. Pierwszy raz jako pleban miejski wystąpił w marcu $1490 \mathrm{r}$. Nie pełnił tej funkcji zbyt długo, na pewno do stycznia $1491 \mathrm{r}$. Nieco później (28 IV 1491) arcybiskup Zbigniew Oleśnicki inkorporował wicearchidiakonat i plebanię miejską do ufundowanego przez siebie kolegium mansjonariuszy. W 1491 roku Jan z Wagańca otrzymał godność kanonika łowickiego, być może beneficjum to było wynagrodzeniem za utracone probostwo uniejowskie w związku z erekcją przez arcybiskupa kolegium mansjonarzy ${ }^{44}$.

W literaturze przedmiotu pojawiają się jeszcze cztery osoby, które w końcu $\mathrm{XV}$ w. miały sprawować funkcję proboszcza uniejowskiego: Jan Kraska, Jan z Lutomierska, Stanisław z Umienia i Marcin Cegiełka z Lutomierska ${ }^{45}$. Jan Kraska miał być plebanem uniejowskim w latach 1488-1492. W tym czasie plebanem

${ }^{40}$ AAG, ACap., A3, k. 13v - 13 III 1483 r. jako pleban w Wieleninie wystąpił Jan z Besku, który zeznał 4,5 grzywny na rzecz Jan Sakowskiego, plebana w Konarach i wikariusza wieczystego uniejowskiego. Jednak już w kwietniu 1483 r. Jan Sakowski ponownie występuje jako pleban w Wieleninie.

${ }^{41}$ A. Gąsiorowski, I. Skierska, Oficjalaty..., s. 122; A. Jabłońska, Kapituła..., s. 201; A. Kowalska-Pietrzak, Duchowieństwo..., s. 144.

${ }^{42}$ Z. Wilk-Woś, Późnośredniowieczna kancelaria..., s. 206, 209.

${ }^{43}$ AAG, ACap., A3, k. 146, 147, 165.

${ }^{44}$ Z. Wilk-Woś, Późnośredniowieczna kancelaria..., s. 209.

${ }^{45}$ A. Kowalska-Pietrzak, Duchowieństwo..., s. 143-144. W tekście wspomniany został jeszcze Paweł, syn Stanisława z Kłodawy. Paweł rzeczywiście otrzymał prowizję na plebanię w Uniejowie, ale w diecezji krakowskiej (Bularium Poloniae, t. 4, nr 444). 
wiejskim jest Leonard, proboszczem miejskim zaś kolejno Piotr i Jan z Wagańca. Jan Kraska jest w tym okresie związany z Uniejowem - przynajmniej od maja 1483 r. pełnił on funkcję archidiakona uniejowskiego, a nieco później również oficjała uniejowskiego ${ }^{46}$. Z uniejowskim środowiskiem kościelnym związany był również Jan, syn Floriana z Lutomierska. Był on kolejno wikariuszem wieczystym kolegiaty uniejowskiej (1482), a potem jej kanonikiem (1494, 1496). Pełnił również funkcję oficjała uniejowskiego $(1494)^{47}$. Jeśli chodzi o Stanisława $z$ Umienia, to przed rokiem 1499 odnotowany został jako kanonik, oficjał i pleban uniejowski ${ }^{48}$. Należy zwrócić uwagę na fakt, że data ta znów przypada na czas po zamianie wicearchidiakonatu w kolegium mansjonarzy i sprawowania funkcji proboszcza wiejskiego przez Leonarda z Oleśnicy. Z drugiej strony interesujące jest to, że funkcja plebańska zdaje się łączona $\mathrm{z}$ funkcją oficjalską. Jeśli zaś chodzi o Marcina Cegiełkę z Lutomierska, to Liber beneficiorum wymienia go przy opisie wicearchidiakonatu. Wydaje się jednak, że Marcin nie był wicearchidiakonem i plebanem miejskim, ale jedynie wikariuszem, który zamieszkiwał w domu należącym dawniej do plebana miejskiego ${ }^{49}$. Przypuszczać można, że dom ten był zbyt mały, aby pomieścić kolegium składające się z siedmiu mansjonarzy.

Interesującym zagadnieniem pozostają wzajemne relacje między plebanami. W źródłach natrafiamy jedynie na kilka wzmianek o konfliktach, do jakich dochodziło między nimi. Liber beneficiorum przekazuje nam jasną sytuację podziału między plebanów terenu parafii, jednak źródła wcześniejsze pokazują, że kwestia ta została ostatecznie uregulowana dopiero w latach czterdziestych XV w. Jeszcze w roku 1444 spór przed sądem arcybiskupim prowadzili bowiem Mikołaj, pleban miejski i Adam, pleban wiejski. Konflikt dotyczył jurysdykcji nad mieszkańcami przedmieścia Uniejowa. Arcybiskup Wincenty Kot zadecydował, że obszar ten przynależy do plebana miejskiego. Jednocześnie zwolnił plebana wiejskiego Adama i jego parafian z obowiązku płacenia denara św. Piotra in iure levitam levite non debere decimam solvere ${ }^{50}$. Kilka lat później - 27 IV 1482 - przed sądem arcybiskupim rozstrzygany był inny spór między plebanami uniejowskimi. Dotyczył on prawa do dochodów z nowo wybudowanego przez starostę uniejowskiego młyna na rzece Warta i Zawada. Piotr, pleban miejski, twierdził, że młyn został zbudowany na obszarze przedmieścia, które podlegało jego pieczy duszpasterskiej. Przeciwnie uważał Jan Dunda, pleban wiejski. Arcybiskup uznał jednak racje Piotra i jemu oraz jego następcom przyznał jeden korzec mąki rocznie, który młynarz miał oddawać na Wielkanoc ${ }^{51}$.

${ }^{46}$ A. Jabłońska, Kapituła..., s. 122-123.

${ }^{47}$ Tamże, s. 154.

${ }^{48}$ A. Kowalska-Pietrzak, Prałaci i kanonicy kapituly tęczyckiej do schyłku XV wieku, Łódź 2004, s. 326.

${ }^{49}$ LB, t. 1, s. 346; podobnie uważa A. Jabłońska, Kapituła..., s. 37.

${ }^{50}$ AAG, ACap., A1, k. 51v; S. Hain, Wincenty Kot prymas Polski (1436-1448), Poznań 1948, s. 74 .

${ }^{51}$ AAG, ACap., A3, k. 26-26v. 
W przypadku kilku proboszczów uniejowskich nie jesteśmy w stanie określić ich pochodzenia terytorialnego i społecznego. Natomiast wśród zidentyfikowanych plebanów widać, że część z nich pochodziła spoza diecezji gnieźnieńskiej. Jan z Wagańca był kapłanem diecezji włocławskiej, a Leonard z Oleśnicy i zapewne Maciej z Wojnicza z diecezji krakowskiej. Natomiast Jana Sakowskiego można uznać za rodowitego mieszkańca dekanatu uniejowskiego. Przedstawicielami stanu szlacheckiego byli Jakub z Gawłowic, Leonard z Oleśnicy, Jan z Wagańca i Stanisław z Umienia, podczas gdy Jan z Lutomierska i Maciej z Wojnicza byli prawdopodobnie mieszczanami. Dodać należy, że dwóch plebanów (Leonard z Oleśnicy i Jan z Wagańca) miało poświadczone źródłowo wyższe święcenia kapłańskie. Niewiele można powiedzieć na temat wykształcenia proboszczów uniejowskich. Zapewne dość gruntowne wykształcenie mogli odebrać Jakub z Gawłowic i Jan z Wagańca, którzy posiadali uprawnienia notariuszy publicznych. Dodatkowo Jan pracował w kancelarii arcybiskupiej, co wymagało od niego określonej wiedzy i umiejętności. Musimy również pamiętać, że niektórzy z wymienionych wyżej plebanów pełnili jednocześnie urząd oficjała uniejowskiego, który wymagał także odpowiednich kompetencji. Warto jeszcze podkreślić wyraźne związki kilku plebanów uniejowskich z arcybiskupami gnieźnieńskimi i ich kancelarią oraz oficjalatem uniejowskim.

Podsumowując, musimy stwierdzić, że nie znamy początków i dokładnej genezy dwuosobowej obsady plebańskiej w Uniejowie. Odpowiedź na te zagadnienia pozostaje nadal $\mathrm{w}$ sferze hipotez. Zmiany $\mathrm{w}$ tej nietypowej sytuacji nastąpiły pod koniec XV w. w związku z powołaniem przez Zbigniewa Oleśnickiego kolegium mansjonarzy. Pytaniem bez odpowiedzi pozostaje także kwestia organizacji życia parafii uniejowskiej. Czy obecność dwóch plebanów miała pozytywny wpływ na funkcjonowanie parafii i ułatwiała wiernym dostęp do sakramentów, czy być może ewentualne konflikty między duchownymi odbijały się negatywnie na funkcjonowaniu parafii?

\section{Bibliografia}

\section{Źródła rękopiśmienne}

Archiwum Archidiecezjalne w Gnieźnie

Akta działalności arcybiskupa Jan Gruszczyńskiego: ACap., A2

Akta działalności arcybiskupa Wincentego Kota: ACap., A1

Akta działalności arcybiskupa Zbigniewa Oleśnickiego: ACap., A3

Depositiones testium, syng. ACons., B3

\section{Źródla drukowane}

Acta Camerae Apostolicae, t. 4: Annatae e Regno Poloniae saeculi XV (1421-1503), wyd. M.D. Kowalski, [w:] Monumenta Poloniae Vaticana, t. 10, Kraków 2002.

Bullarium Poloniae, t. 4, wyd. S. Kuraś, I. Sułkowska-Kuraś, H. Wajs, Romae-Lublin 1992.

Długosz J., Liber beneficiorum dioecesis Cracoviensis, wyd. A. Przeździecki, t. 2, Kraków 1864.

Joannis Dlugossi Annales seu Cronicae incliti Regni Poloniae, lib. 9, Varsaviae 1978. 
Kodeks dyplomatyczny Wielkopolski, t. 2, wyd. I. Zakrzewski, Poznań 1878; t. 3, wyd. I. Zakrzewski, Poznań 1879; t. 5, wyd. F. Piekosiński, Poznań 1908; t. 7, wyd. A. Gąsiorowski, R. Walczak, Warszawa-Poznań 1985.

Łaski J., Liber beneficiorum archidiecezyi gnieźnieńskiej, wyd. J. Łukowski, t. 1, Gniezno 1880.

Wykazy święconych z najstarszej księgi akt działalności biskupów włocławskich, wyd. W. Kujawski, „Archiwa, Biblioteki i Muzea Kościelne”, 72, 1999.

\section{Opracowania}

Abraham W. (rec.), Schmid H. F., Die rechtlichen Grundlagen der Pfarrorganisation auf westslavischem Boden und ihre Entwicklung während des Mittelalters, „Kwartalnik Historyczny”, 44, 1930.

Bilska-Ciećwierz M., Powstanie $i$ organizacja kapituł kolegiackich metropolii gnieźnieńskiej w średniowieczu, Kraków 2007.

Gąsiorowski A., Notariusze publiczni w Wielkopolsce schyłku wieków średnich, Poznań 1993.

Gąsiorowski A., Skierska I., Oficjalaty okręgowe w późnośredniowiecznej archidiecezji gnieźnieńskiej, „Czasopismo Prawno-Historyczne”, 47, 1995, s. 93-124.

Hain S., Wincenty Kot prymas Polski (1436-1448), Poznań 1948.

Jabłońska A., Kapituła uniejowska do początków XVI wieku, Kielce 2005.

Kowalska-Pietrzak A., Duchowieństwo parafialne w późnośredniowiecznej Polsce centralnej. Archidiakonat łęczycki i uniejowski, Łódź 2014.

Kowalska-Pietrzak A., Prałaci i kanonicy kapituły łęczyckiej do schyłku XV wieku, Łódź 2004.

Kowalska-Pietrzak A., W kręgu średniowiecznego duchowieństwa tęczyckiego, Łódź-Łęczyca 2012.

Kowalska-Pietrzak A., Spory duchownych i świeckich w Polsce centralnej, [w:] Dynamika przemian społecznych i religijnych w średniowieczu, red. T. Grabarczyk, T. Nowak, Warszawa 2011.

Kujawski W., Rola instytucji kościelnych w życiu miasta, [w:] Uniejów. Dzieje miasta, red. J. Szymczak, Łódź-Uniejów 1995.

Maleczyński K. (rec.), Michael Edmund: Die schlesische Kirche und ihr Patronat. I. Die Schlesische Kirche und ihr Patronat im Mittelalter unter polnischem Recht. Beiträge zur ältesten schlesischen Kirchengeschichte. Görlitz, Reiber (1926), str. 288, mapa, „Kwartalnik Historyczny", 41, 1927.

Osmałek M., Parafie z wieloosobowa obsadq plebańska $w$ diecezji krakowskiej $w$ średniowieczu, „Summarium. Sprawozdania TN KUL”, 26-27 (46-47), 1997/1998.

Szymański J., Wokót genezy organizacji parafialnej w Polsce, „Przegląd Historyczny”, 55, z. 3, 1964.

Szymczakowa A. (rec.), A. Jabłońska, Kapituła uniejowska do początku XVI wieku, Kielce 2005, ss. 218, „Rocznik Łódzki”, 52, 2005.

Wieteska J., Katalog prałatów i kanoników prymasowskiej kapituły łowickiej od 1433 do 1470 r., Warszawa 1971.

Wilk-Woś Z., Późnośredniowieczna kancelaria arcybiskupów gnieźnieńskich (1437-1493), Łódź 2013.

Wiśniowski E., Parafie w średniowiecznej Polsce. Struktura i funkcje społeczne, Lublin 2004.

[Wpłynęło: kwiecień 2016; akceptacja: maj 2016] 


\title{
ON PARISH PRIESTS IN $15^{\mathrm{TH}}$ CENTURY UNIEJÓW
}

\begin{abstract}
Summary
In the $15^{\text {th }}$ century, the Uniejów parish was one of a few parishes in Poland which had two parsons: one who took care of parishioners living in the town, and the other - of parishioners in rural areas. The paper characterizes the $15^{\text {th }}$ century group of Uniejów parish priests as well as addresses a broader issue of parishes with more than one priests, including property regulations and mutual relations between the parsons.
\end{abstract}

Keywords: Uniejów, parish priests, $15^{\text {th }}$ century 